\title{
The Diversity of State Benefit Dependent Lone Mothers: the Use of Type Categories As an Analytical Tool
}

\author{
by Martina Klett-Davies \\ London School of Economics \\ Sociological Research Online, Volume 10, Issue 1, \\ < http://www.socresonline.org.uk/10/1/klett-davies.htm/> \\ doi: $10.5153 /$ sro. 1049
}

Received: 16 Mar 2004 Accepted: 21 Jan 2005 Published: 31 Mar 2005

\begin{abstract}
This article provides an empirical examination of how lone mothers who receive state benefits in Germany and Britain create meaning with regards to mothering and state dependency. It uses the concept of individualisation as it requires women to negotiate their own lives. But the concept of individualisation is limited as it insinuates a convergence in men's and women's work identities and aspirations and is in danger of reducing women's identity to their 'family-work' preferences that does not encompass the complexity of their lives.
\end{abstract}

The article has both a methodological claim and a substantive claim: Methodologically, it explores how new type categories can be used as an analytical tool to help us understand how lone mothers create meaning and to make sense of the differences between the mothers' complex identities. Substantively, these type categories demonstrate that there are great variations and dynamics in mothers' identities despite their state dependency. Based on lone mothers' perceived choices and constraints they are categorised as pioneers, copers or strugglers. The pioneers view their situation as an opportunity to construct their lives actively in non-traditional ways. In contrast, the coper and the struggler types perceive a lack of choices and tend to have traditional gender role values. While copers view their situation as temporary and improvable, strugglers feel overwhelmed by constraints and perceive themselves to have no choices at all. This article discusses the construction and the characteristics of these categories while detailed case studies bring each type category to life and give them more substance. The data analysis also shows that besides values, lone mothers' structural background as well as the number and age of their children seems to be related to lone mothers' creation of meaning.

\section{Keywords: Choices/constraints, Individualisation, Lone Motherhood, Type Categories, Sense of Coherence Concept, Structural Background}

\section{Introduction}

1.1 This article provides an empirical examination of how lone mothers who receive state benefits create meaning with regards to mothering and state dependency. The article has both a methodological claim and a substantive claim: Methodologically, new analytical type categories are used as a tool to make sense of the differences between the mothers' complex identities. Substantively, these type categories demonstrate that the structural background and state benefits influence but not determine lone mothers' perception of choices and constraints as other factors are relevant too.

1.2 There has been much research into lone motherhood. The social policy discipline is mainly concerned with lone mothers' relative deprivation and that of their children and how to improve their situation through paid employment, related benefits and policies (Ford, 1998;Bryson, Ford and White, 1997;Kilkey, 2000; Millar and Ridge, 2001). Sociological informed research incorporates a feminist perspective and constructs lone motherhood historically and contextually while building connections between changes in gender relationships, employment patterns, morality and sexualities (Smart and Neale, 1999;Silva, 1996;Silva and Smart, 1999;Duncan and Edwards, 1999;Lewis et al., 1998). This body of work illustrates how 'family' relationships have become more diverse, self-reflexive and negotiated, both in response to conditions and as a source of wider changes. In this sense it is influenced by Beck and Beck-Gernsheim's concept of individualisation. Family studies approaches tend to place more stress on the social negotiation of identities and moralities, or family practices (Morgan, 1996; Finch and Mason, 1993;Smart and Neale, 
1999). Hence, Silva and Smart (1999) want to move policy making away from what family member should do to what people do in families. My work builds on this and takes the agenda forward to include lone mothers who are solely dependent on state benefits for their income.

1.3 Giddens (1997; pp.157) divides lone mothers into two groups only; those 'by choice' and those 'in poverty'. He notes that self-actualisation and empowerment vary according to economic resources which are influenced by class divisions, gendered and ethnic inequalities. This approach emphasises the effect of structural disadvantage and this article illustrates the variations and dynamics in lone mother's selfactualisation and empowerment despite their state dependency. My research uses the concept of individualisation as it allows for diversity as well as choice but also recognises the relevance of economic resources. As part of 'reflexive modernisation' the process of individualisation assumes that biographies are no longer pre-determined by religion, tradition or the state but have to be actively chosen instead in a 'do-ityourself-biography' (Beck and Beck-Gernsheim, 2002; Lash 2002). ${ }^{[1]}$

1.4 The concept of individualisation is a suitable framework for exploring the diversity of lone mothers who are receiving state benefits but the research also finds it quite narrow. The concept generates an expectation of convergence in men's and women's work identities and aspirations. The process of women's 'individualisation' is mainly linked to changes in education and to the increase in women's paid employment rate. But because of persistent gender inequalities and identities women are caught in the process of individualisation between a 'no longer' and 'not yet' . For women the individualisation process is 'incomplete' which generates numerous ambivalences and contradictions in women's lives (Beck and Beck-Gernsheim, 2002: 56). Although Beck and Beck-Gernsheim would like to refrain from taking the position of men as a yardstick, the adult-worker model is continually used to explain women's 'delayed' individualisation (and men's 'complete' individualisation). This may be ill-advised. Lewis (2001) critiques the 'adult worker model' as it ignores the crucial gap between gender egalitarian expectations and a reality that is still far from equality and which also has to be negotiated. In reality, women mostly work part-time and continue to do more unpaid work that attracts low monetary and social value (Lewis, 2002). Lewis (2001) maintains that 'doing gender' remains powerful especially with respect to unpaid work and Wajcman and Martin (2002) have already explained the gender structuring of 'choices' as men and women face quite different dilemmas in 'family-work' decision making. The type categories in this article show that a paid employment outlook is only one of many categories that make up lone mothers' identity.

1.5 Most lone mothers in this study negotiated their lives in relation to their responsibilities for their children and to their own personal development. Rather than speaking of a 'delayed' individualisation this article makes the case that mothers experience a 'different' individualisation. This 'different' individualisation could be conceptualised by exploring women's complex identities (personal, mothering, partnership, social) rather than by just relating them to paid employment and mothering.

1.6 Three type categories of mothers with distinct patterns arose from the analysis of the in-depth interviews. Based on lone mothers' perceived choices and constraints they are categorised as pioneers, copers or strugglers. The pioneers view their situation as an opportunity to construct their lives actively in non-traditional ways. In contrast, the coper and the struggler types perceive a lack of choices and tend to have traditional gender role values. While copers view their situation as temporary and improvable, strugglers feel overwhelmed by constraints and perceive themselves to have no choices at all. This article describes my construction and the characteristics of these categories in order to explore the concept of 'different' individualisation while detailed case studies bring each type category to life and give them more substance.

\section{Research Methodology: About the Study}

2.1 My research is based on in-depth interviews with 70 state-dependent lone mothers Germany and Britain with lone mothers who received state benefits (Income Support or its German equivalent Sozialhilfe), were mostly unmarried, heterosexual and had at least one pre-school child. The interviews were conducted over a period of three years (summer 1996 - summer 1998).

2.2 These two countries were chosen because of their different academic and public discourses and contrasting social policies for lone mothers. While the German welfare state has been described as conservative and corporatist, the British welfare state is a liberal regime 'in which means tested assistance, modest universal transfers, or modest social-insurance plans predominate.' (Esping-Andersen 1990). Hantrais (1994) proposes that for state dependent lone mothers it is more advantageous to live in Britain than in Germany and Daly (1996) finds Britain the better 'gender equaliser' although the German welfare state may more effectively alleviate relative deprivation. However, in Germany - and this is not well publicised - lone mothers are treated differently according to the age of their child. Mothers with small children are financially rewarded for staying at home while mothers with older children are financially punished and expected to be in educational or vocational training or in paid employment despite rising 
unemployment and although schools and Kindergartens only operate half a day. In spite of this, lone mothers in Germany are not only more likely to be in paid employment than their married counterparts, they are also more likely to be in paid work than lone mothers in Britain. Hence, they are less likely to be state dependent. In 1994, about 24 per cent of lone mothers with dependent children relied on state benefits but in Britain in 1995, 63 per cent of lone mothers received Income Support (Bradshaw 1998; Statistisches Bundesamt 1996).

2.3 This may partly explain that more German than British lone mothers in the sample would like to combine caring for their children with part-time paid work ( $23 \%$ and $11 \%$ respectively). The London mothers are more likely to have a full-time mothering orientation ( $48 \%$ and $34 \%$ respectively). These orientations may not be lone mothers' choice but constraints - circumstances and perceptions - may have led them to have this current outlook. London mothers may 'resign' to a mothering orientation because they perceive themselves in a poverty trap while on the other hand, they may legitimise their mothering orientation with perceived constraints. The Labour Party, which came to power in 1997, promotes paid work as the best way out of poverty. Recent research shows that social policies that encourage lone mothers into paid employment - such as in-work benefits and, from 1999, tax credits played an important role in helping lone parents enter work, providing they stopped having children (Marsh and Vegeris 2004). The Labour Government has also been increasingly involved in childcare through the 1998 National Childcare Strategy. This indicates that under the Labour Government, Britain is about to follow a more individual welfare state model. However, the interviews were conducted with lone mothers with pre-school children and at a time when lone mothers were de facto neither positioned as workers nor carers but as state dependants in both, the reunited Germany and Britain.

2.4 According to the concept of individualisation 'new' lifestyles may be more pronounced in urban centres (Beck and Beck-Gernsheim, 1990). I have conducted 35 interviews in the urban boroughs of Berlin (16 in West Berlin and 19 in East Berlin) and 35 interviews in London that happen to have the countries' highest proportion of lone mothers and are particularly deprived.

2.5 Theoretically, the inductive approach of grounded theory and gendered approach of feminist epistemology enabled me to describe the most relevant discourses that emerged from the lone mothers' accounts (Glaser and Straus, 1967; Stanley and Wise, 1993). The interviews are based on the 'life-history' approach as this is more holistic because it does not narrow the interview to predetermined topics (Ribbens, 1994). My interviews lasted about one and a half-hours and took place in the mothers' homes. All interviews were tape recorded, transcribed and analysed using Nudist 4.0. Several sampling methods were used. In Berlin, I approached lone mothers who were waiting in the corridors of the benefit offices in person, with the approval of state benefit departments. In London, I stood in front of post offices on the days that state dependent lone mothers cashed in their Income Support or Child Benefit cheques. Snowballing and placing advertisements in classified newspapers were also used to gain access. This sample compares quite well with national statistics in Britain and Germany which validates the construction of the type categories. In this sample, the majority of mothers have one child only $(n=45 / 70)$ and tend to come from a working-class background (50/70). Most are white (55/70) but the ethnic minority mothers tend to live in London (13/35).

\section{The Use and Development of Type Categories}

3.1 The use of type categories is widespread in academic literature, particularly in German poverty research (Jahoda et al., 1971;Leisering and Leibfried, 1999;Ludwig, 1996;Mädje and Neusüß, 1994). In Britain, Duncan \& Edwards (1999) use crude type categories to distinguish between 'worker', 'mother' and 'worker/mother integral' orientation that does not encompass the complexity of these women's lives. Hakim (2000) has used categories that describe women's work-family orientation based on individual preferences. Hakim's 'preference theory' highlights some of the dilemmas associated with typologies. She has developed three typologies, the 'work-centred', the 'family centred' and the 'adaptive' woman. Besides playing down external constraints and neglecting different capacities for overcoming constraints, Hakim's categories underestimates that preferences vary over the lifecycle, and especially vary with the age and number of children, social policies and structural backgrounds. 3.2 I take a more holistic view and persist with the use of 'real' types (as supposed to Weber's ideal types). Real types offer an overview of the data and relate cases and their characteristics. Moreover, finding commonalities among the diversity of lone mothers not only heightens our understanding of them but also can offer guidance for social policy. I have developed my three type categories by contrasting cases along an agency/structure continuum (Archer, 1995). Agency consists of personal and social identities and is not just dependent on the individual's capability or power to 'do' things but also on their perception and identity to 'do' things, as a creative capacity (Schilling, 1997).

3.3 My research examines lone mothers' reflexive shaping of self-identity and finds that it cannot be reduced to material circumstances. Some 'poor' lone mothers are able to enrich their lives and to negotiate their life satisfactorily despite scarce financial resources. Therefore, the main objective in the development 
of type categories is to take a holistic view and a multidimensional approach on single mothering and not just their coping strategies under economic pressure that assumes a lack of agency. The 'sense of coherence concept' (SOC) is a useful tool for finding out about mothers' coping strategies that influence the perception of their confidence and complex identities.

\section{The Sense of Coherence Concept}

4.1 Antonovsky (1987) works within the sociology of health and has been keen to explain the origins of health - of successful coping with stressors. Antonovsky has developed the SOC concept to explain successful coping with stressors - life situations as well as events. The SOC concept is defined as:

"a global orientation that expresses the extent to which one has a pervasive, enduring though dynamic feeling of confidence that (1) the stimuli deriving from one's internal and external environments in the course of living are structured, predictable and explicable; (2) the resources are available to one to meet the demands posed by these stimuli; and (3) these demands are challenges, worthy of investment and engagement." (Antonovsky 1987: 19).

4.2 Thus, successful coping is dependent on being able to make sense of the stressor (comprehensibility), to strike a successful balance between demands and capabilities (manageability) and to be flexible in selecting coping behaviours (meaningfulness). The comprehensibility concept assumes a tendency to expect stimuli that confront one as making cognitive sense, as information that is ordered, consistent, structured, and clear, rather than chaotic, random, inexplicable and accidental. The manageability component assumes the tendency to expect the demands posed by these problems to be manageable. In other words, it evaluates the locus of control or a confidence that 'things will work out' (Antonovsky 1987). A tendency to see life as meaningful provides the motivational drive to engage in confrontation with the problems. Meaningfulness is the emotional component of the three concepts and it incorporates the social valuation of the person's activity by either society or by significant others.

4.3 In-depth qualitative research is ideally suited for this approach as it can detect different factors that may influence the categories. I have tried to operationalise this approach by breaking it down into a series of assessments used in the interviews, particularly in lone mothers' negotiating process with state benefits and lone mothering. A strong SOC provides a 'strong' basis for successful resolution of problems, has a positive impact on well-being and acts as a stress-buffer (Antonovsky and Sourani 1990).

4.4 The SOC is made up of three intertwined components: manageability, comprehensibility and meaningfulness. Hence, these components are being examined with regard to particular 'variables' that came out of the data and that could be grouped into mothers' perceived experiences with the past, the present and the future. The past concerns issues such as their childhood, debts and illnesses. The present and the future include their evaluation of mothering, state benefits, relative deprivation, housing, paid work, education, relationships and social support networks. Future plans or a general outlook on life are also a good coping indicator.

4.5 Operationally, lone mothers' accounts have been organised according to these particular 'variables'. Their characteristics were then examined according to the three components that make up the SOC concept: manageability, comprehensibility and meaningfulness. The evaluation of these 'variables' according to this principle led to the formation of three groups of lone mothers: those with high, medium and low SOC's. Lone mothers with a low SOC feel that most aspects of their lives are unmanageable, incomprehensible and meaningless. The individual case studies that follow show in more detail how the three levels of SOC were identified. The concept itself proved an invaluable tool that could be used as the basis for the creation of three type categories, especially as the SOC concept is informed by the data and their differences - and not by preconceived ideas about a typology.

4.6 Nonetheless, the type categorisation needed to be extended beyond the SOC concept to include other potential reasons for lone mothers' confidence and identity. Factors such as cultural and socio-demographic backgrounds and constraints also need to be examined. According to my judgement based on a thorough analysis of the interviews, three distinctive patterns arose out of the data that could make sense of the differences between the mothers' complex identities: 'pioneer', 'coper' and 'struggler'. 'Pioneers' have the highest SOC while 'strugglers' have the lowest SOC. In other words, 'pioneers' convey the sense that most aspects of their life situation are particularly manageable, comprehensible and meaningful. For example, a 'pioneer' is able to manage her situation between demands and capabilities and finds it meaningful to be a full-time mother and can make sense of her situation. In contrast, 'strugglers' feel that most aspects of their lives are unmanageable, incomprehensible and meaningless. The 'copers' may 'score' high on one component and low on another but are likely to have many mediocre SOC ratings in the relevant variables. 
5.1 Of the three distinctive patterns that arose out of the data, pioneers feel in control of their lives not only because they necessarily created their present life style intentionally but because they embrace change positively. This resembles Sennett's (1998) 'surfer' types who accept that decisions must and can be made under conditions of uncertainty and this feeds an optimistic outlook in life. Strugglers perceive that they have no control of their lives because they see it as externally determined. This bears some similarity to Sennett's (1998) 'drifter' types who experience the contingency and fragmentation of life as a loss and a threat.

5.2 Table 1 presents a useful summary as it describes the characteristics that I found relevant when analysing the interviews with state dependent lone mothers. They vary distinctively between each type category. While some variables describe lone mothers' negotiating process with mothering, paid work, state benefits and education for example, other variables describe general experiences, such as the experience of domestic violence and the perception of their own childhood. I have included all characteristics that were specific to each type category and have not distinguished between their explanatory and their descriptive values. Although they are obviously related, the research cannot prove that they are interdependent. I do not even distinguish between lone mothers' orientation and their situation because in my opinion, even their situation is a construct of their orientation, an evaluation.

Table 1. Type Categories and Characteristics

\begin{tabular}{|l|l|l|l|}
\hline $\begin{array}{l}\text { Type category } \\
\text { characteristics }\end{array}$ & Pioneer & Coper & Struggler \\
\hline $\begin{array}{l}\text { Perception of } \\
\text { situation }\end{array}$ & Based on choices & $\begin{array}{l}\text { Based on choices \& } \\
\text { constraints }\end{array}$ & Based on constraints \\
\hline Comments & $\begin{array}{l}\text { 'I've got what I want' } \\
\text { is self-fulfilled }\end{array}$ & $\begin{array}{l}\text { 'Make the best out of } \\
\text { situation' }\end{array}$ & $\begin{array}{l}\text { 'All goes wrong and } \\
\text { feel paralysed' }\end{array}$ \\
\hline $\begin{array}{l}\text { Sense of } \\
\text { Coherence } \\
\text { Concept (SOC) }\end{array}$ & Highest SOC & Medium SOC & Lowest SOC \\
\hline $\begin{array}{l}\text { Evaluation of } \\
\text { situation }\end{array}$ & $\begin{array}{l}\text { Highly satisfied } \\
\text { Is chosen \& actively } \\
\text { created: 'professional' } \\
\text { mothering } \\
\text { career break, catalyst }\end{array}$ & $\begin{array}{l}\text { Satisfied as situation } \\
\text { is temporary. } \\
\text { Desire to mother but } \\
\text { mainly because of } \\
\text { lack of alternatives }\end{array}$ & $\begin{array}{l}\text { Very unsatisfied, } \\
\text { despairs, is } \\
\text { apathetic, hopeless, } \\
\text { feels paralysed }\end{array}$ \\
\hline $\begin{array}{l}\text { State benefits } \\
\text { evaluation }\end{array}$ & $\begin{array}{l}\text { Is used to fulfil } \\
\text { ambitions/ } \\
\text { Wage for mothering }\end{array}$ & $\begin{array}{l}\text { Ambivalent but ok } \\
\text { temporary because of } \\
\text { lack of alternative }\end{array}$ & $\begin{array}{l}\text { Is a right, the least } \\
\text { the state can do }\end{array}$ \\
\hline $\begin{array}{l}\text { Relative } \\
\text { deprivation }\end{array}$ & $\begin{array}{l}\text { Money is low priority, } \\
\text { anti-consumerist } \\
\text { attitude }\end{array}$ & $\begin{array}{l}\text { Yes, but halted by } \\
\text { budgeting, casual } \\
\text { work or Childrearing } \\
\text { Benefit }\end{array}$ & $\begin{array}{l}\text { Yes, accelerated by } \\
\text { the inability to } \\
\text { budget \& debts }\end{array}$ \\
\hline $\begin{array}{l}\text { Partnership } \\
\text { orientation }\end{array}$ & $\begin{array}{l}\text { None or latent male } \\
\text { breadwinner } \\
\text { expectation }\end{array}$ & $\begin{array}{l}\text { None or mostly male } \\
\text { breadwinner } \\
\text { orientation }\end{array}$ & $\begin{array}{l}\text { None. Fear of } \\
\text { repeating negative } \\
\text { experiences }\end{array}$ \\
\hline Paid employment & $\begin{array}{l}\text { Not in work by choice } \\
\text { imot searched or not } \\
\text { found because of } \\
\text { constraints }\end{array}$ & $\begin{array}{l}\text { Not found or not } \\
\text { searched because of } \\
\text { constraints }\end{array}$ \\
\hline Education & $\begin{array}{l}\text { No or yes to improve } \\
\text { labour market } \\
\text { chances, facilitate } \\
\text { mothering or bridge } \\
\text { unemployment }\end{array}$ & $\begin{array}{l}\text { No or vague } \\
\text { aspiration }\end{array}$ \\
\hline
\end{tabular}




\begin{tabular}{|l|l|l|l|} 
Education & $\begin{array}{l}\text { No or yes to primarily } \\
\text { improve personal } \\
\text { development }\end{array}$ & $\begin{array}{l}\text { No or yes to improve } \\
\text { labour market } \\
\text { chances, facilitate } \\
\text { mothering or bridge } \\
\text { unemployment }\end{array}$ & $\begin{array}{l}\text { No or vague } \\
\text { aspiration }\end{array}$ \\
\hline Stigmatisation & $\begin{array}{l}\text { No or doesn't care if } \\
\text { yes }\end{array}$ & $\begin{array}{l}\text { No or yes because of } \\
\text { conformist attitude }\end{array}$ & Yes \\
\hline $\begin{array}{l}\text { Lone mothers' } \\
\text { social policy } \\
\text { Recommendation }\end{array}$ & $\begin{array}{l}\text { None or perhaps } \\
\text { fewer regulations }\end{array}$ & $\begin{array}{l}\text { Less regulation, more } \\
\text { training, education \& } \\
\text { labour market support }\end{array}$ & $\begin{array}{l}\text { More fin ancial \& } \\
\text { labour market } \\
\text { support }\end{array}$ \\
\hline $\begin{array}{l}\text { Childhood } \\
\text { perception }\end{array}$ & Mostly positive & Neut ral or negative & Very negative \\
\hline $\begin{array}{l}\text { Domestic violence } \\
\text { experience }\end{array}$ & Mostly no & Sometimes & Always \\
\hline $\begin{array}{l}\text { Support network } \\
\text { (family, friends) }\end{array}$ & Satisfactory & $\begin{array}{l}\text { Satisfactory or } \\
\text { unsatisfactory }\end{array}$ & Perceived isolation \\
\hline Outlook & Optimist & Pragmatist & Pessimist \\
\hline
\end{tabular}

5.3 I am careful about the distinction between lone mothers' intentional and unintentional 'doings' and concentrate my type categorisation on lone mothers' identity and confidence. For example, a 'professional' mother is a 'pioneer type' if her primary goal is the upbringing of her child/ren and the desire to provide childcare herself. A 'professional' mother is a 'coper' when she cannot find alternatives for example and does not value mothering as a vocation. Education and paid work is another indicator for the categories. It may be that lone mothers' outlook to mothering, education and/or paid work is related to their categorisation. Pioneer and coper cases may feel highly satisfied about mothering or may have an education outlook that facilitates mothering while struggler borderline cases are dissatisfied about full-time mothering and would like to be in paid work instead. Furthermore, 'pioneer' types may be in education for personal development and as a means for self-fulfilment while 'coper' types are more 'practical' and want to increase their labour market chances and their income potential.

\section{The Pioneer Type Category}

6.1 The pioneer types may live an 'alternative lifestyle' and perceive themselves to have choices. The pioneer viewed motherhood and state dependency as a positive event in their life, as an achievement which they may or may not have chosen intentionally. For a couple of mothers lone motherhood was the only option of motherhood as they were not in a close relationship and perceived their fertility as decreasing. For the pioneer state-dependent full-time motherhood can have several meanings. It may serve as a 'career break' or it can act as a 'catalyst' whereby motherhood was a key milestone in making a biographical change, a transformation (Baily, 1999). State benefits may be an anticipated result of action and are used strategically as a means to facilitate a life style choice such as full-time mothering, artistry, education and hobbies. State benefits are perceived as a citizens' right, as a wage for mothering and as a fair exchange for paying taxes in the past. The pioneer's family and friends are not always supportive and the research could not find that the pioneer is part of a particular sub-culture as found by Duncan \& Edwards (1999).

6.2 The pioneer type perceives their socio-economic interests and employment as secondary after their personal interests. Living with a small income is a temporary 'worth-while' sacrifice and sometimes even viewed as an asset. Of course, it is sometimes difficult to assess whether the pioneer woman does perhaps just post-rationalise, or self-justify a situation that she has not 'really' chosen. Nonetheless, she embraces changes more positively than the coper and struggler type.

\section{The Coper Type Category}

7.1 The coper is a pragmatist and manages a problem satisfactorily even if her ultimate goal is out of reach. She regards internal and external factors responsible for her situation and accepts her situation on state benefits as temporary although she has no specific end in sight. State benefits are accepted as a legitimate form to secure a living as a temporary arrangement only and facilitate 'coping' while accumulated savings or casual work may ease the financial deprivation. This type uses their benefits constructively and 'makes the best' out of a situation.

7.2 The coper can have a paid employment orientation but at the same time her expectations, needs and skills may not be compatible with the labour market. She may not be prepared to work full-time and is unable to demand a sufficient wage working part-time. She appears to 'resign' to full-time motherhood or education but also does not lower her job expectations. Education may be used to enhance job opportunities or to facilitate part-time mothering as it tends to be more flexible. Children give meaning and help to get over crisis situations. In contrast to the struggler the coper type can rely on social support from 


\section{The Struggler Type Category}

8.1 The struggler type is characterised through her low sense of coherence (SOC) and low self-esteem. Everything seems too much for her and she despairs, is apathetic or highly dissatisfied. She has difficulties in rearing her children, problems with institutions, with budgeting and debts and she feels financially deprived. She blames the 'system' or institutions for her situation. Her contact with the local state benefit offices and Job Centres are perceived as negative and discriminatory. As a lone mother on state benefits, she feels stigmatised and excluded from a society to which she would like to belong but never has, not even before she became a mother. The struggler feels lonely, has little or no social network and is disappointed that friends and family are not offering support. She blames her children and the unsatisfactory childcare system for her unemployment and state dependency. In my study, the struggler type also had experienced domestic violence and a negative childhood. Some of these women may suffer from depression and/or drug addictions. It is noteworthy that these characteristics are not necessarily class specific. For example, domestic violence is not a problem confined to lower socio-economics groups (Dobash and Dobash, 1992;Schröttle, 1999).

8.2 The next section discusses one case study for each type category to provide a detailed and in-depth account of the mother's creation of meaning as supposed to concentrating on family-work dilemmas. The pioneer and the coper type are from the German sample purely for illustration purposes and they are not a reflection of the findings in the respective welfare states.

\section{Case Study of a Pioneer}

9.1 Anne was born into a middle-class family in East Berlin. Her father was a theatre actor and her mother a housewife. She was at 44 years the oldest mother in the sample. Her son was six year old. She trained to become a theatre hairdresser and make-up artist and worked in film and TV. She always wanted to have a child and saved up for it because it was never her intention to combine work and mothering. Therefore, only after fifteen years in paid employment was she ready to give up work. Only then she felt that she had reached a certain maturity that allowed her to cope with a child.

9.2 When she was 38 , Anne had a son with her actor partner of 12 years who was unable to support them. He was unemployed and did not live with them. Anne only applied for state benefits when her savings were all gone. She felt that state benefits were a fair exchange for her tax contributions in the past. According to state benefit regulations she should have been searching for paid work once Moritz was three years old. But instead, she negotiated an additional three years Childrearing Leave with the authorities. Anne viewed state benefits as a privilege that enabled her to stay at home with her son. She managed well on a low income of about 300 Euros (£150) a month after bills partly because she knew it was only temporary and partly because she perceived her anti-consumerist attitude as a virtue.

I don't need anything, because I have everything. I have everything but no new items. I don't need anything, nothing. I don't need clothes. I don't need anything new. I have no television set. I can live with what I've got. Somehow it works, because I told myself, it is much nicer and more important that we experience something rather than consume something (...) I can cope well on state benefits. I have no problems whatsoever and I am not embarrassed at all. The opposite is the case. That I can receive Income Support now and be able to stay at home, that makes me proud and happy; that I have the opportunity to care for my child and the state pays for this.

9.3 Anne dedicated her life to her child in that she made sure that she was always available to him and she let him decide how and where they spent their time. For example, she rarely met her friends because she didn't want to exclude Moritz and leave him to play by himself. She also went to bed with him until he was asleep when she got up again to do the domestic chores. Furthermore, being child centred, she felt that she could not be a partner as well as a parent. Her son saw his father about twice a week. She did not want to be in paid employment because she was convinced that the children of working mothers experience separation anxiety. This anxiety was her reason for breastfeeding Moritz for five years, until he gave it up himself:

The children of working mothers will have an unfulfilled life because they constantly yearn after comfort and intimacy (Geborgenheit), because they have never experienced it during their childhood. And that results in communication difficulties, in paranoia, and partnership problems. I think that nature designed it that way, that the children cut the umbilical cord to the mother and not the other way around. In our society I feel it's the other way round. They cannot get rid of the feeling that they are constantly left by someone. 
9.4 I define Anne as a pioneer because she negotiated her set of values without much support from her friends and family nor by being part of a particular sub-culture. Her views may be essentialist and naturalistic but they are her own. Although Anne realised that her situation was only temporary she had no immediate plans to return to paid employment and was unaware of her chances for employment. When I interviewed her for the second time one year later she still had no immediate plans to return but was involved in volunteer work at the alternative private school her son attended and for which he won a scholarship. Although she lived on a very low income she did not feel poor because state benefits enabled her to realise full-time mothering. She created meaning mainly about state dependency and mothering rather than her lone motherhood situation and her relationship with the father of her child which was less important.

\section{Case Study of a Coper}

10.1 Steffi was 26 years old and had a three year old daughter in West Berlin. Her mother was working class, a lone mother and had looked after four children. But when Steffi was eight years old she re-married a postman who Steffi thought of as her father or 'dad'. Steffi left school with her GCSEs and trained for two years to become a dental assistant. She continued working for a further five years until her Childrearing Leave. Her pregnancy was unplanned but welcomed by both her and her partner of two years, a physiotherapy student. After one year childrearing leave, Steffi returned to work, sending her daughter to a childminder. Although her employer was initially keen for her to return to work in his small dental practice, he fired her six months later because he was concerned that her child's potential for illness would make her attendance unreliable: 'Everyone told me I should take him to court and I said no, all doctors stick together. And when you take him to court you will never get a job again.'

10.2 Initially, she was very optimistic about finding another job as a dental assistant but she has had 20 unsuccessful job interviews for a part-time job in the last one-and-a-half years. She felt discriminated against because she had a child but she was also disadvantaged because of her insufficient computer and $\mathrm{x}$-ray skills. She enrolled on a computer course but was not prepared to compromise on the hours she worked. This was influenced by her experience of 'bad' mothering when she had previously worked full-time:

My partner's sister was my childminder and I paid her to care from eight in the morning until seven or seven thirty. (...) That worked quite well but also in a negative way and I was disappointed and hurt because she started saying 'mama' to the childminder. That is my main reason for not wanting to work full-time anymore. (...) I want to work part-time to have some space for myself somehow, to do things for myself. Somehow I want a distraction too, and not only be a mother but to have responsibility for other things. And I like my job. It makes me more balanced.

10.3 The father did not pay any child maintenance but she was only marginally worse off living on state benefits. Although she felt ambivalent about state dependency she justified it as a fair exchange for her paying taxes in the past and because she tried to get paid work. She also valued state benefits as an enabler:

Nowadays it is made easy to give up on a family. I do like it that there is such a thing (state benefits). Otherwise you wouldn't know what to do at all. Then you really would have to live on the street with your child. Somehow you are really supported as a lone mother.

10.4 Steffi did not want to send her three-year old daughter into a Kindergarten while she was still unemployed. She and her partner separated but she had hopes that they would eventually get back together again and he saw their daughter once or twice a week. They had drifted apart because of his long studying and working hours but this meant that her situation has not changed much as she was mostly alone with her daughter anyway.

10.5 Steffi is an interesting case because of her experience of employer discrimination and her integral working/mothering outlook. Steffi is categorised as a coper because she was ambivalent about state dependency by evaluating it as stigmatising as well as enabling. She is a pragmatist and only managed not to feel stigmatised because she hid the fact that she was dependent on state-benefits. She is a coper because she felt positive about the temporary nature of her situation and made the best out of her mothering situation. She perceived some but not all aspects of her situation as meaningful, manageable and comprehensible. She made internal and external factors responsible for her unemployment but financially, she coped satisfactorily. She experienced employment discrimination and it is a fact that dental assistants are typically female, young, independent and flexible, although she hardly mentioned her lack of certain vocational qualifications in her explanation. 
11.1 Jane was white, 21 years old and had a three year old boy and an eight months old daughter. She was born in London to working-class parents who were on Income Support for most of their lives. She had her first experience of care away from home when she was still a baby:

There are certain things my social worker has told me, like from three months old I had bruises all over my head, my face (...) My dad used to beat me all the time. I was put in care for a little while when I was a baby. Then my parents got me back and from the age of 13, 14, my dad sexually abused me. I was locked in my bedroom. With a bucket as a toilet. (...) When my dad was in prison, I set my mom's flat on fire. I set the whole house on fire.

11.2 She ran away from home and although she requested foster care she also ran away from foster families because she found the places too strict. Instead, she lived on the streets. At school Jane was bullied because of her cleft pallet and her learning difficulties and she left school at 15 with no qualifications. She became pregnant but her partner left her for her 15 year old sister who also became pregnant by him. She was against abortion and always wanted children albeit at a later stage as she was homeless at that time.

11.3 She hoped to consolidate her situation with another partner and had a second child, a daughter. She was devastated when she learned that this partner had fathered a child with another woman at the same time. Her partner left both mothers and although he came to visit about once a month he had no relationship with his daughter and did not pay maintenance because he was unemployed. Her son's father denied fatherhood and was no longer traceable. These experiences influenced her very negative view of men. Financially, she experienced serious deprivation because she could neither budget nor manage on her benefits. 'Sometimes I have to borrow money. I can't budget. I have never been taught how to budget money. Never. So when my money was in my hand, it is gone the same day.' She felt under enormous pressure and feared losing her children:

I've got to make sure everything is alright. My kids will be taken off me and put into care because I haven't got enough money to support my kids. And it is not right. It is not fair. (...) Sometimes my daughter is not well, like she has diarrhea whatever. I haven't got the money to buy her nappies. (...) Last year I was homeless and my son went into foster care (for four months while she registered herself as homeless to get a flat).

11.4 Jane regretted that she left school at such an early age but remained ambivalent about education and vocational training. She preferred to stay at home with her daughter (her son went to a nursery) because she was afraid of the abuse her daughter may experience because she had been abused when she was a child.

11.5 Her situation was a vicious circle because she suffered from depression and became even more depressed over the fact that her children saw her in that state. She felt socially excluded because she didn't like to go out for fear of stalkers and harassment and she could not rely on support from her family: "I hate being on my own. I hate being a lone parent. I never asked to be a lone parent.' She regretted her children and had an injection that stopped her from becoming pregnant again. Jane had been treated for depression but she stopped taking anti-depressants because they made her sick. Throughout her life she had been in contact with institutions and she had a social worker. She perceived her situation as unmanageable, meaningless and incomprehensible. She had low self-esteem, was lonely and felt poor and isolated. She had ambivalent and paradoxical views on work and full-time mothering and she also felt too paralyzed to enquire about education and paid employment. Jane blamed external factors for her situation but perhaps this is not so surprising if we look at her negative childhood experiences.

\section{Borderline Cases}

12.1 Not all of the 70 cases fall neatly into the three type categories but bear characteristics of two adjoining type categories. Aside from copers, pure versions of the three type categories are comparatively rare with most of the 'pioneers' and 'strugglers' being composites with 'copers'. The borderline cases are therefore almost more 'real' than the 'pure' cases but they are not an indicator for the limitation of the type categories as they are 'sandwiched' between them. In fact, borderline cases clarify the type cases' characteristics and offer insights into a more rounded conception of lone mothers' identities. But it could also be argued that they show that 'real' life is more complex and 'messier' than the three analytical categories can capture.

12.2 A borderline case of a mother between the coper and the struggler type category has little confidence and agency. She views her situation as a result of undesirable events and her situation may not be 'stable' but prone to crisis which may be related to health problems. She may not have a clear aim but somehow aspires to paid employment, a male breadwinner, childcare and/or education. She makes external and 
internal factors responsible for her situation which when coupled with the knowledge of her own limits is experienced as stressful and further lower her self-worth. Financial deprivation and debts may be an issue but are not an overwhelming problem.

12.3 One example of a coper/struggler is Erna who was 28, white and lived in East Berlin. She was just about satisfied with her situation. She became a mother to escape the parental home and she became a lone mother to escape a violent relationship. Lone mothering was not a financial sacrifice for her because she was not better off with her partner. Her Job Centre organised a placement in a garden centre as her low self-esteem and inflexible childcare hours prevented her from applying for jobs. She was also a struggler because she had no social network, suffered from shyness and was bored and lonely. She expected external institutions to improve her situation and aspired to a modernised male breadwinner contract.

12.4 The borderline case between coper and pioneer tries to be conscious of change in an attempt to steer it. She makes the most out of her situation and state benefits facilitate her sense of autonomy. This mixed type may not necessarily use income support as a 'means to an end' but unlike the coper, she does not necessarily feel the need for change. Here, personal interests are as important as economic interests. State dependency is used for personal development, for therapy, for learning or full-time mothering.

12.5 Laura, 33, white, lived in London and was a borderline case between coper and pioneer. She was adopted into a working-class family and left school with no educational qualifications. A criminal record served as a catalyst for her to change her ways and to enter paid employment as a criminal investigator. She was thrown off balance when her first child was stillborn but a second child acted as a second catalyst and made her stop criminal activities, taking drugs, change her friends and become a 'professional' mother which makes her a pioneer. Nonetheless, she is also a coper because worked cash in hand to hide her deprivation from her friends and neighbours. The transformation into a 'good' mother was an achievement that gave Laura the confidence and motivation to pursue education in the near future. Ideally, she would have liked a partner who was not a "loser" but a male breadwinner.

\section{Comparison of Type Cases' Background}

13.1 Giddens (1997) notes that self-actualisation and empowerment vary according to economic resources which are influenced by class divisions. While this statement is simplistic it does seem that the sense of coherence (SOC) concept is influenced by structural background. ${ }^{[2]}$

Table 2. Lone Mothers' Background according to Type Category

\begin{tabular}{|c|c|c|c|c|c|c|}
\hline \multirow[t]{2}{*}{ Type } & \multicolumn{2}{|c|}{$\begin{array}{l}\text { Working } \\
\text { Class }\end{array}$} & \multicolumn{2}{|c|}{$\begin{array}{l}\text { Middle } \\
\text { Class }\end{array}$} & \multicolumn{2}{|c|}{ Total $^{*}$} \\
\hline & $\mathrm{N}$ & $\%$ & $\mathrm{~N}$ & $\%$ & $\mathrm{~N}$ & $\%$ \\
\hline Pioneer & 3 & 38 & 5 & 62 & 8 & 100 \\
\hline $\begin{array}{l}\text { Pioneerl } \\
\text { coper }\end{array}$ & 15 & 63 & 9 & 37 & 24 & 100 \\
\hline Coper & 17 & 71 & 7 & 29 & 24 & 100 \\
\hline $\begin{array}{l}\text { Coperl } \\
\text { struggler }\end{array}$ & 11 & 92 & 1 & 8 & 12 & 100 \\
\hline Struggler & 2 & 100 & 0 & 0 & 2 & 100 \\
\hline
\end{tabular}

- Percentages may not add up to $100 \%$ due to rounding

13.2 Table 2 illustrates that the structural background influences experiences and the construction of meaning - but does not determine - the three types. Working-class lone mothers cope well but are seldom 'pure' pioneers while middle-class mothers are seldom to be found in the coper/struggler or struggler category but in the pioneer or coper type categories. While the percentage of middle-class mothers falls from the pioneer through to the struggler category, the percentage of working-class mothers rises from the struggler through to the pioneer/coper category. Hence, lone mothers, who are in a similar situation with regards to income level and state dependency, create very different meanings out of their experiences 
13.3 Nonetheless, women's perception of their choices and constraints also seems to be influenced by age, ethnicity and the number of their children. Pioneers tend to be the oldest in the sample while strugglers are the youngest (35 and 26 respectively). In the sample, the pioneers are all white and and have the least number of children. Together with the pioneer/copers they are also the best educated. The two strugglers are white, have no educational qualifications and more than one child. In this sample, the women in the coper and coper/struggler type category happen to be more likely to belong to an ethnic minority. The Afro-Caribbean and African lone mothers in the London sample seem to connect 'good' mothering with paid employment. These women tend to discuss the difficulties of finding employment and other research confirms this (Duncan, 2003).

13.4 This study is not based on a representative sample but tables 1 and 2 show that identities may not be as socially negotiated as family studies imply (Finch and Mason, 1993;Smart and Neale, 1999;Silva and Smart, 1999). Recently, Duncan (2003) has critiqued these approaches for conceptualising every action as actively negotiated, voluntaristic and self-reflexive rather than a non-negotiable pre-given, particularly with respect to caring responsibilities. Instead, Duncan demonstrates the importance of class and ethnicity that influences how individuals create and experience themselves. While I consider the social positions of lone mothers too I find limitations in referring actions to them and have shown that age, children, ethnicity and the outlook on life matter too. The factors that are found relevant for type categorisation could be explored further through statistical analysis and the next section provides some comparative analysis with regard to the German and British social contexts.

\section{Differences between Berlin and London Lone Mothers}

14.1 Although Berlin and London have similar proportions of strugglers, copers and pioneers, the German and the British welfare state may influence the categorisation. In Berlin, the pioneers and coper/pionees come from East rather than from West Berlin and in the London sample, there are more pioneer/coper types and fewer coper/strugglers.

Table 3. Type Categorisation according to Location

\begin{tabular}{|l|l|l|l|l|l|l|l|l|}
\hline & \multicolumn{2}{|l}{ London } & \multicolumn{2}{l|}{ Berlin } & \multicolumn{2}{l|}{$\begin{array}{l}\text { East } \\
\text { Berlin }\end{array}$} & \multicolumn{2}{l|}{$\begin{array}{l}\text { West } \\
\text { Berlin }\end{array}$} \\
\hline & $\mathbf{n}$ & $\%$ & $\mathbf{n}$ & $\%$ & $\mathrm{~N}$ & $\%$ & $\mathbf{n}$ & $\%$ \\
\hline Pioneer & 4 & 11 & 4 & 11 & 4 & 21 & 0 & 0 \\
\hline Coper/Pioneer & 13 & 37 & 11 & 31 & 7 & 37 & 4 & 25 \\
\hline Coper & 13 & 37 & 11 & 31 & 5 & 26 & 6 & 38 \\
\hline Coper/struggler & 3 & 9 & 9 & 26 & 3 & 16 & 6 & 38 \\
\hline Struggler & 2 & 6 & 0 & 0 & 0 & 0 & 0 & 0 \\
\hline Total & 35 & $100^{*}$ & 35 & 100 & 19 & 100 & 16 & 100 \\
\hline
\end{tabular}

*Percentages may not add up to $100 \%$ due to rounding

14.2 East Berlin mothers may have a higher Sense of Coherence (SOC) than West Berlin mothers because they are less conventional and do not necessarily miss a partner while West Berlin mothers are more conformist and feel stigmatised. They would like to comply with the male breadwinner/ female homemaker model, desire a flexible and sufficiently paid job or struggle financially because they no longer receive the Childrearing Benefit. In some cases, the Job Centre pressures them into finding paid employment although paradoxically, social institutions encourage mothers to place childrearing over participation in the labour market. East Berlin mothers are more independent and concentrate on their own education or mothering. This may be a left over from their socialist East German past which did not discriminate against lone mothers but encouraged women to be in education although they also had to be financially independent, mainly through paid work.

14.3 Nonetheless, the East German mothers in the sample are also younger, tend to come from more middle-class backgrounds and have on average higher qualifications. They seem to be more adaptable and ready for change despite the fact that statistically, lone mothers in East Germany are more likely to be in paid employment than in West Germany and in Britain. However, it appears that the middle class East Berlin lone mothers in the sample seem to have more in common with middle-class and working-class London lone mothers as both welcome the chance to escape binding identities. 


\section{Concluding Discussion}

15.1 This article is a result of a grounded theory analysis and provides an extension to thinking about the perspectives of lone mothers on their situation by not reducing it to the mothering/paid employment angle. This extension also effectively shows that mothers negotiate their do-it-yourself biography diversely and dynamically despite apparently common characteristics such as state dependency.

15.2 This article has discussed the use of type categories as an analytical tool that helps us understand how mothers create meaning and illustrates their dynamics, complexity and temporality. The type categories have been constructed based on the Sense of Coherence Concept that categorises the confidence with which lone mothers live and cope with various aspects of their situation. This concept operationalises agency which is found to be intertwined with structural processes and country differences. Lone mothers' construction of meaning and their sense of coherence is related with their structural background as well as location, age, ethnicity and age and number of children and their past experiences.

15.3 The main finding of this research is that the construction of state dependent mothering as meaningful, comprehensible and manageable depends on the perception of it as a choice or as a constraint. That apparent constraints can be interpreted as choices is best illustrated in the pioneer who can be considered self-fulfilled because she uses state benefits as a resource for the active creation of her biography. Here, the idea and the reality of her situation overlap. The pioneer may not even be aware of constraints such as lack of labour market opportunities because they are deemed irrelevant to her current identity. This finding does not support Hakim's preference theory as the other types are aware of constraints and have different capacities for overcoming them.

15.4 There are only a few mothers in the pioneer and in the struggler category in this sample but it is not the quantity of women who exactly fit each type category but the qualities of them that this article addresses. The pioneers are quite self-fulfilled as they do not necessarily have pre-conceived views over their lives but embrace change in a positive way. In the words of Zygmunt Bauman (1996) pioneers could also be 'tourists' in the way that they are incessant seekers of experiences to escape binding identities although their identity is very much fixed through motherhood. Of course, there are also mothers who are able to change their identity to sustain a positive self-image but even this post-rationalisation indicates a dynamic identity and a reflexive biography. In fact, pioneers incorporate most character traits that are relevant for succeeding in today's society according to Beck and Beck-Gernsheim (1994). They can adapt to new circumstances, can improvise and design aims. They are not easily discouraged nor constrained by social expectations nor particular cultures. Pioneers have successfully built their 'do-it-yourself biography' while struggler's biographies have turned into a 'breakdown biography'.

15.5 This analysis also shows that the dualistic de-traditionalisation thesis, which is an important part of the concept of individualisation, is unsuitable to explain the lives of lone mothers. The type categories show that it is not useful to think of these oppositional terms in order to conceptualise how meaning is being created. Instead of focussing on the replacement of tradition, we should focus on the simultaneous existence of de-traditionalisation and traditionalisation and their mutual implication (Adam 1996). Detraditionalisation can almost be considered as an addition rather than replacing traditional norms and values. Women seem to have developed their old and fixed identity as wives and mothers but take gender still as a reference point. However, it is no longer clear cut what constitutes traditional or modern behaviour. Full-time mothering can be interpreted as traditional or modern or both. For example, the resistance to paid employment may be evaluated as an escape from some aspects of public patriarchy, such as the masculine model of employment. Paradoxically, this 'radical feminist' viewpoint can also be informed by the traditional view of the female homemaker and carer. Therefore, women negotiate their lives within both traditional and non-traditional views.

15.6 Type categories that just distinguish between lone mothers mother/paid work orientations are unable capture the complexities and dynamics of lone mothers' identities. The same is true for the 'adult worker model' that is used to explain 'delayed' individualisation. Women don't experience a 'delayed'

individualisation but a 'different' individualisation. The concept of 'different' individualisation is helpful because it highlights that lone mothers' 'do-it-yourself' biography is negotiated within their perception of choices and constraints, their caring responsibilities and family relationships that cannot be reduced to 'family-work' dilemmas and 'worker/mother' categories.

15.7 The concept of individualisation is useful to explain that typical constraints such as state benefits and being a lone mother can be viewed as enabling too in the quest to construct a 'do-it-yourself' biography. A lone mother negotiates her situation on her perception of choices, that is the 'subjective' agency rather than the 'objective' agency. However, the concept of individualisation underplays that there is still a line between the advantaged and the disadvantaged. A middle-class mother may have more social capital that enables her to use the welfare state as a 'tool' to suit her life style providing she has a value system that enables 
her to be a proud state dependent lone mother, such as the pioneer.

15.8 Borderline categories may be especially relevant for social policy as they reveal the dynamics and the transitions of the women between the categories. The women in these categories may also be most receptive to new social policies such as the 'New Deal' or 'Sure Start' as long as they recognize that different types of lone mothers have complex needs that are not limited to paid work and child care. However, since the study has shown that structural backgrounds and not necessarily the income level is influential in mothers sense of coherence concept, one could argue for the increase of social capital of all lone mothers. The debate could be held regarding educational and vocational training, child care and social stigmatisation, social networks etc. instead of just about income levels, paid work and state dependency.

15.9 Paid work may not be the best form of welfare as it attaches a very low value to care work. One way to avoid essentialising motherhood and undervaluing gendered inequalities is to support the 'capabilities approach' that promotes not just material well being but human capital and the freedom to choose political and social life as well as life in the family (Nussbaum and Sen, 1993). This approach provides a way of recognising and valuing care by addressing the distribution of time. Pioneers appear to live this model already as they value the time spend out of paid employment and perceive this a result of choice.

\section{Notes}

${ }^{1}$ It is a common misconception that individualisation means autonomy, emancipation and self-liberation of humanity (Burkart 1993).

2 The distinction between working-class and middle-class is made based on the 'highest' profession of either lone mothers' mother or father since few lone mothers have a professional occupation.

\section{Acknowledgements}

The research for this article was funded by Economic and Social Research Council Award No R00429634353. I would like to thank the three anonymous referees for cogent and constructive comments on the article. Above all, many thanks to the lone mothers who were so generous in giving their time, and for sharing their thoughts about, and experiences, of being a state-benefit receiving lone mother.

\section{References}

ADAM, B. (1996) 'Detraditionalization and the certainty of uncertain futures', in P. Heelas, S. Lash and P. Morris (editors) Detraditionalization. Oxford: Blackwells.

ANTONOVSKY, A. (1987) Unravelling the Mystery of Health. San Francisco: Jossey-Bass Inc.

ANTONOVSKY, A. and Sourani, T. (1990) 'Family sense of coherence and family adaptation', in A. Antonovsky (editor) The Sociology of Health and Health Care in Israel. New Brunswick: Transaction Publishers.

ARCHER, M. S. (1995) Realist Social Theory: the Morphogenetic Approach. Cambridge: Cambridge University Press.

BAILY, L. (1999) 'Refracted selves? A study of changes in self-identity in the transition to motherhood', Sociology Vol. 33, No. 2, pp. 335-352.

BAUMAN, Z. (1996) 'From pilgrim to tourist - or a short history of identity', in S. Hall and Du Gay (editors) Questions of Cultural Identity. London: Sage.

BRYSON, A., Ford, R. and White, M. (1997) Making Work Pay - Lone Mothers, Employment and Well Being. York: Joseph Rowntree Foundation.

BECK, U. and Beck-Gernsheim, E. (1990) Das ganz normale Chaos der Liebe. Frankfurt a.M.: Suhrkamp.

BECK, U. and Beck-Gernsheim, E. (1994) 'Individualisierung in modernen Gesellschaften', in U. Beck and E. Beck-Gernsheim (editors) Riskante Freiheiten, Frankfurt a. M.: Suhrkamp.

BECK, U. and Beck-Gernsheim, E. (2002) Individualization. London: Sage.

BRADSHAW, J. (1998) 'International comparisons of support for lone parents', in R. Ford and J. Millar 
(editors) Private Lives and Public Responses - Lone Parenthood and Future Policy in the UK. London: Policy Studies Institute.

BURKART, G. (1993) 'Individualisierung und Elternschaft - Das Beispiel USA', Zeitschrift für Soziologie Vol. 22, No. 3, pp. 159-177.

DALY, M. (1996) 'The gender division of welfare: the British and German welfare states compared', PhD thesis, Florence, European University Institute

DOBASH, R. E. and Dobash, R. P. (1992) Women, Violence and Social Change. New York: Routledge.

DUNCAN, S. and Edwards, R. (1999) Lone Mothers, Paid Work and Gendered Moral Rationalities. London: MacMillan.

DUNCAN, S. (2003) 'Mothers, Care and Employment: Values and Theories', CAVA Working Paper May 2003. Bradford: University of Bradford.

ESPING-ANDERSEN, G. (1990) The Three Worlds of Welfare Capitalism, Cambridge, Polity Press.

FINCH, J. and Mason, J. (1993) Negotiating Family Responsibilities. London: Routledge.

FORD, R. (1998) 'Lone mothers' decisions whether or not to work: childcare in the balance', in Ford, R. and Millar J. (editors) Private Lives and Public Responses - Lone Parenthood and Future Policy in the UK. London: Policy Studies Institute.

GIDDENS, A. (1997) Sociology. $3^{\text {rd }}$ edition. Cambridge: Polity Press.

GLASER, B. G. and Strauss, A. L. (1967) The Discovery of Grounded Theory: Strategies for Qualitative Research.. Chicago: Aldine.

HAKIM, C. (2000) Work-lifestyle Choices in the $21^{\text {st }}$ Century - Preference Theory. Oxford: Oxford University Press.

HANTRAIS, L. (1994) 'Comparing family policy in Britain, France and Germany', Journal of Social Policy , Vol 23, No. 2, pp. 135-160.

JAHODA, M., Lazarsfeld, P.- F. and Zeisel, H. (1971) Marienthal - The Sociography of an Unemployed Community. Chicago: Aldine Atherton.

KILKEY, M. (2000) Lone mothers between paid work and care: the policy regime in twenty countries . Aldershot: Ashgate.

LASH, J. (2002) 'Foreword: Individualization in a non-linear mode', in Beck, U. and E. Beck-Gernsheim (editors.) Individualization. London: Sage.

LEISERING, L. and Leibfried, S. (1999) Time and Poverty in Western Welfare States: United Germany in Perspective. Cambridge: Cambridge University Press.

LEWIS, J., Kiernan, K. and Land, H. (1998) Lone motherhood in twentieth-century Britain: from footnote to front page. New York: Clarendon Press.

LEWIS, J. (2001) The End of Marriage? Individualism and intimate relations. Edward Elgar: Cheltenham.

LEWIS, J. (2002) 'Gender and Welfare State Change', European Societies Vo. 4, No. 4, pp. 331-357.

LUDWIG, M. (1996) Armutskarrieren - Zwischen Abstieg und Aufstieg im Sozialstaat. Opladen: Westdeutscher Verlag.

MARSH, A. \& Vegeris S. (2004) The British Lone Parent Cohort and their Children. Research Report No 209. London: Department for Work and Pensions.

MÄDJE, E. and Neusüß, C. (1994) 'Frauen im Sozialstaat: Subjektive Deutungen, Orientierungen und staatliches Handeln am Beispiel alleinerziehender Sozialhilfeempfängerinnen', Dissertation: Freie Universität Berlin.

MILLAR, J. and Ridge, T. (2001) 'Families, poverty, work and care: a review of the literature on lone parents and low-income couples and families with children', Research Report No. 153. Leeds: Department for Work 
and Pensions.

MORGAN, D. (1996) Family Connections. Cambridge: Polity Press.

NUSSBAUM, M. and Sen A. (editors) (1993) The Quality of Life. Oxford: Oxford University Press.

RIBBENS, J. (1994) Mothers and their Children: a Feminist Sociology of Childrearing. London: Sage.

SCHILLING, C. (1997) 'The under socialised conception of the embodied agent in modern sociology', Sociology, Vol. 31, No. 4, pp. 737-754.

SCHRÖTTLE, M. (1999) Politik und Gewalt im Geschlechterverhältnis. Bielefeld: Kleine Verlag.

SENNETT, R. (1998) The Corrosion of Character: the Personal Consequences of Work in the New Capitalism. New York: Norton.

SILVA, E. B. (editor) (1996) Good Enough Mothering - Feminist Perspectives on Lone Motherhood. London: Routledge.

SILVA, E.B. and Smart, C. (1999) 'Introduction', in E.B. Silva and Smart, C. (editors) The New Family?, London: Sage.

SMART, C. and Neale, B. (1999) Family Fragments?. Cambridge: Polity Press.

STANLEY, L. and Wise, S. (1993) Breaking Out Again - Feminist Ontology and Epistemology. London: Routledge.

STATISTISCHES BUNDESAMT (1998) Haushalte und Familien 1997. Lange Reihen. Wiesbaden: Metzler Poeschel.

WAJCMAN, J. and Martin, B. (2002) 'Narratives of Identity in Modern Management: The Corrosion of Gender Difference', Sociology, Vol. 36, No: 4, pp. 985-1002. 